\title{
Disturbed $\alpha$-Adrenergic Modulation of Insulin and Growth Hormone Secretion in Chronic Alcoholics
}

\author{
A. Nygren ${ }^{1}$ and L. Sundblad ${ }^{2}$ \\ Departments of ${ }^{1}$ Medicine II and ${ }^{2}$ Clinical Chemistry, Södersjukhuset, Stockholm, Sweden
}

Summary. The effect of $\alpha$-adrenergic stimulation by IV adrenaline and propranolol infusion upon basal insulin and growth hormone secretion was studied in six chronic alcoholics during alcohol withdrawal, two alcoholics recently admitted to hospital with alcoholinduced hypoglycaemia and twelve healthy subjects. In all healthy subjects a decline in basal insulin (mean \pm SEM decremental area $166 \pm 19$ ) and an increase in growth hormone (mean \pm SEM incremental area $527 \pm 164$ ) was found. In the two alcoholics admitted to hospital with alcohol hypoglycaemia, no consistent change occurred in basal insulin and basal growth hormone concentrations during $\alpha$-adrenergic stimulation. In the other alcoholics a decrease in basal insulin (mean \pm SEM decremental area $91 \pm$ 13.5) was found, but this decrease was significantly less $(\mathrm{p}<0.05)$ than in healthy subjects. Growth hormone did not change significantly in these alcoholics. It is concluded that disturbances in the $\alpha$-adrenergic modulation of basal insulin and growth hormone secretions are common in alcoholics in a withdrawal state. The implication of this finding for the occurrence of alcohol-induced hypoglycaemic coma is discussed.

Key words: Alcohol hypoglycaemia, insulin secretion, growth hormone secretion, blood glucose, adrenaline, adrenergic effects, chronic alcoholism, alcohol withdrawal.

Alcohol-induced fasting hypoglycaemia has been attributed to inhibition of gluconeogenesis by alcohol [1], but abnormal counter-regulatory responses to a decline in blood glucose may also be involved [2] Adrenergic mechanisms have been claimed to play a major role in the initiation of counter-regulatory responses to insulin-induced hypoglycaemia in man [3].

The aim of this study was to compare the effect of $\alpha$-adrenergic stimulation by IV adrenaline and propranolol infusion upon basal insulin and growth hormone secretion in normal subjects and alcoholics in a withdrawal state. We also wished to investigate the role of disturbed $\alpha$-adrenergic modulation of insulin and growth hormone secretion in the occurrence of clinical hypoglycaemia in alcoholics.

\section{Material and Methods}

\section{Patients}

Alcohol-induced Hypoglycaemia. Two male alcoholics (cases 1 and 2), aged 50 and 56 years, 104 and 109\% ideal body weight, respectively [4], who had been admitted to hospital in hypoglycaemic coma (blood glucose 1.8 and $2.0 \mathrm{~m} \mathrm{~mol} / \mathrm{l}$ ), were investigated. Both had a history of heavy alcohol intake and poor caloric intake before admission. Case 2 had adult onset diabetes treated by diet alone. In this patient fasting blood glucose varied between 9-14 $\mathrm{m} \mathrm{mol} / 1$ during the hospital stay. Neither patient had clinical or biochemical evidence of advanced liver disease or other endocrine disorder (plasma bilirubin, alkaline phosphatase and prothrombin index within the normal range; plasma aspartate aminotransferase varied between $0.5-0.9 \mu \mathrm{kat} / 1$, normal $<0.7 \mu \mathrm{kat} / \mathrm{l}$ ). The investigations described in this report were performed on the third to the fifth day after admission to hospital.

Alcoholics. Six male chronic alcoholics, aged 37-52 years, were examined on the third to fifth day after admission in an intoxicated state. Mean ideal weight was $107 \%$ (range $81-128 \%$ ) [4]. They had consumed $0.3-0.751$ spirits (schnaps or vodka) daily for one to four weeks before admission to hospital. They showed signs of alcohol withdrawal (gross tremor, perspiration, tachycardia and general anxiety), but no concurrent medical problems. All patients were treated with tranquillizers (clomethiazol $0.9-1.8 \mathrm{~g}$ and nitrazepam $5 \mathrm{mg}$ per day), but none were given during $12 \mathrm{~h}$ prior to the investigation described in this report. All patients were fed a 
Table 1. Mean ( $\pm \mathrm{SEM}$ ) change in serum insulin (mU/1), serum growth hormone (mU/l) and blood glucose $(\mathrm{m}$ mol/l) in six alcoholics and twelve healthy subjects (controls) during adrenaline-propranolol infusion

\begin{tabular}{|c|c|c|c|c|c|c|c|}
\hline & \multirow[t]{2}{*}{ Subjects } & \multirow{2}{*}{$\begin{array}{l}\text { Before } \\
\text { infusion }^{a}\end{array}$} & \multicolumn{4}{|c|}{ Minutes after start of infusion } & \multirow{2}{*}{$\begin{array}{l}\text { Decremental area } \\
\text { or incremental area }\end{array}$} \\
\hline & & & 15 & 25 & 35 & 45 & \\
\hline Serum & Alcoholics & $10.2 \pm 1.5$ & $-1.8 \pm 0.7$ & $-2.0 \pm 0.7$ & $-3.5 \pm 0.9$ & $-2.1 \pm 0.8$ & $-91 \pm 13.5^{\mathrm{b}, \mathrm{c}}$ \\
\hline Insulin & Controls & $8.7 \pm 0.9$ & $-5.2 \pm 0.8$ & $-5.0 \pm 0.5$ & $-4.8 \pm 0.5$ & $-3.9 \pm 0.6$ & $-166 \pm 19^{c}$ \\
\hline Serum & Alcoholics & $4.0 \pm 1.1$ & $-0.6 \pm 0.6$ & $+5.7 \pm 2.7$ & $+27.2 \pm 12.6$ & $+32.8 \pm 23.2$ & $397 \pm 289$ \\
\hline Growth hormone & Controls & $0.9 \pm 0.2$ & $+5.1 \pm 3.5$ & $+13.9 \pm 6.0$ & $+19.4 \pm 5.7$ & $+21.9 \pm 6.0$ & $527 \pm 164^{c}$ \\
\hline Blood & Alcoholics & $4.6 \pm 0.2$ & $+0.2 \pm 0.1$ & $+1.1 \pm 0.3$ & $+2.1 \pm 0.3$ & $+3.3 \pm 0.3$ & $44.5 \pm 7.8^{b, c}$ \\
\hline Glucose & Controls & $4.3 \pm 0.1$ & $0.5 \pm 0.1$ & $+1.9 \pm 0.1$ & $+2.9 \pm 0.2$ & $+3.8 \pm 0.3$ & $76 \pm 5.0$ \\
\hline
\end{tabular}

a In each individual the mean value of three baseline samples was used for the calculation of group mean value

b Significantly different from controls $(\mathrm{p}<0.05)$

c Mean decremental or incremental area significantly different from zero $(p<0.05)$

normal diet with a caloric content of $9200 \mathrm{~kJ}$ ( $50 \%$ carbohydrate, $30 \%$ fat and $20 \%$ protein).

\section{Controls}

Nine healthy men and three women, aged 24-60 years, were examined. Mean ideal body weight was 101\% (range 94-109\%).

\section{Procedure}

All studies were performed in the morning after an overnight $(10 \mathrm{~h})$ fast. Teflon catheters $(1.15 \mathrm{~mm}$ diameter $)$ were introduced into antecubital veins in both arms and patency of the catheters maintained by slow infusion of $0.154 \mathrm{~mol} / 1$ sodium chloride. After cannulation subjects rested for 15 minutes. Three baseline samples were then collected over $20 \mathrm{~min}$ before infusion. Propranolol ( $3 \mathrm{mg}$ ) was given as an IV bolus followed by infusion of propranolol $(0.08 \mathrm{mg} / \mathrm{min})$ and adrenaline $(6 \mu \mathrm{g} / \mathrm{min})$ for $45 \mathrm{~min}$ using a Holter pump. Blood was drawn from the contralateral arm at $10,15,25,35$ and $45 \mathrm{~min}$ after the start of the infusion. The nature and purpose of the study was fully explained to the subjects before obtaining their voluntary consent. The study was approved by the Hospital Medical Ethical Committee.

\section{Chemical Determinations}

Insulin [5] and growth hormone (Phadebas hGH Prist, Pharmacia, Sweden) were assayed in serum by radioimmunoassay. Blood glucose was determined with a glucose oxidase method (Glox, AB Kabi, Sweden). Student's t-test was used for statistical analysis.

\section{Results}

Insulin. In healthy subjects infusion of adrenaline combined with propranolol produced a decrease in circulating insulin concentrations. In the alcoholics insulin levels also fell during adrenaline-propranolol infusion, but the fall was significantly less than in controls (Table 1). Case 1 showed an initial rise and subsequent fall in insulin concentrations; in case 2 insulin levels were unchanged by adrenaline-propranolol infusion (Fig. 1).

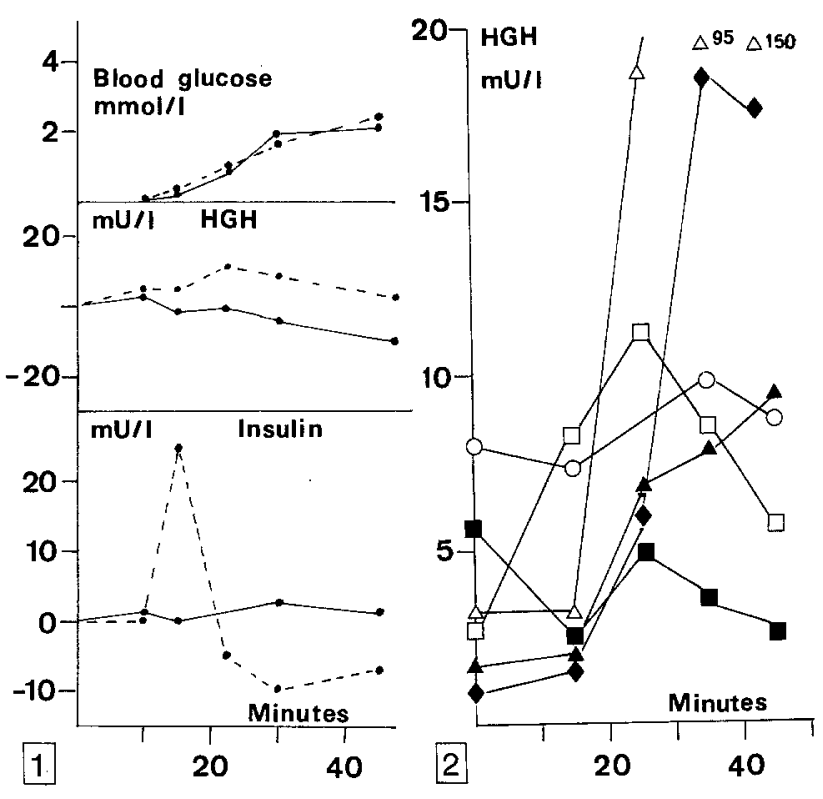

Fig. 1. Change from basal level (the mean of three baseline samples) in blood glucose, serum growth hormone and serum insulin in case 1 and 2 during adrenaline-propranolol infusion. Case 1 ; -...- Case 2

Fig. 2. The serum growth hormone level during adrenaline-propranolol infusion in six chronic alcoholics. Zero value is the mean of three baseline samples

Growth Hormone. In all normal subjects growth hormone concentrations increased during the adrenaline-propranolol infusion (Table 1). Response in alcoholics was variable, with 2 subjects showing no change and 4 subjects a rise in growth hormone levels, which was delayed in three (Fig. 2). In cases 1 and 2 growth hormone levels did not change during adrenaline-propranolol infusion (Fig. 1).

Blood Glucose. Blood glucose concentration rose during adrenaline-propranolol infusion in controls 
and all alcoholic patients (Table 1, Fig. 1). In healthy subjects the mean \pm SEM incremental area was 76 \pm 5.0 , which was significantly greater than that obtained in the alcoholics $(44.5 \pm 7.8, \mathrm{P}<0.05)$.

\section{Discussion}

In normal subjects $\alpha$-adrenergic stimulation resulted in a decrease in basal insulin and an increase in basal growth hormone secretion, as demonstrated by other workers $[6,7]$. In alcoholics, however, the $\alpha$-adrenergic effect upon basal insulin and growth hormone secretion was blunted. This was most evident in the two patients recently admitted to hospital in hypoglycaemic coma, one of whom showed a transient rise in insulin concentrations. It seems likely that the blunted effect of $\alpha$-adrenergic stimulation upon basal insulin and growth hormone secretion is a specific finding in alcoholics related to their alcohol abuse. Transient inappropriate insulin secretion has been described in alcoholic hypoglycaemia [8]. A recent study with insulin and C-peptide measurements in five patients with alcoholic hypoglycaemia showed insulin and C-peptide levels within the normal fasting range [9]. At the low blood glucose concentrations found in these patients, however, insulin secretion should have been further suppressed [9]. The decreased ability of $\alpha$-adrenergic stimulation to suppress insulin secretion in alcoholics may be important in the development of alcoholic hypoglycaemia.

An absent cortisol and growth hormone response to insulin hypoglycaemia has been reported in alcoholics [10, 11] and may reflect a defect in hypothalamic-pituitary control of ACTH and growth hormone secretion $[12,13]$. Catecholamines influence growth hormone secretion by effects mediated at a hypothalamic level [13]. The blunted growth hormone response to $\alpha$-adrenergic stimulation may indicate a further defect of hypothalamic pituitary function in alcoholic subjects which may contribute to the development of hypoglycaemia.

During insulin hypoglycaemia catecholamine release increases, resulting in decreased peripheral glucose utilization and an increase in hepatic glucose production, thereby producing an increase in blood glucose concentration [3]. In this study the blood glucose increase to adrenaline-propranolol infusion was diminished in the alcoholics compared with the blood glucose response in healthy subjects. The alcoholics had been given a normal hospital diet for three days or more before the examination was performed. Thus it is unlikely that the poor blood glucose increase in alcoholics was due to depleted glycogen stores in the liver. The blunted blood glucose response in the alcoholics may reflect a decreased ability of $\alpha$ adrenergic stimulation to increase hepatic glucose production.

\section{References}

1. Field JB, Williams HE, Mortimor GE (1963) Studies on the mechanism of ethanol-induced hypoglycaemia. J Clin Invest 42: 497-506

2. Marks V (1978) Alcohol and carbohydrate metabolism. Clin Endocrinol Metab 7: 333-349

3. Garber A J, Cryer P E, Santiago J. V, Haymond M. W, Pagliasa AS, Kipnis DM (1976) The role of adrenergic mechanisms in the substrate and hormone response to insulin induced hypoglycaemia in man. J Clin Invest 58: 7-15

4. Documenta Geigy (1962) Scientific tables, six ed. J R Geigy S A, Basle, p 624

5. Soeldner J S, Slone D (1965) Critical variables in the radioimmunoassay of serum insulin using the double antibody technic. Diabetes 14: 771-779

6. Robertson RP, Porte D (1972) Adrenergic modulation of basal insulin secretion in man. Diabetes 22: 1-8

7. Blackard W G, Heidingsfelder S A (1968) Adrenergic receptor control mechanism for growth hormone secretion. J Clin Invest 47: 1407-1414

8. Hed R, Nygren A, Röjdmark S, Sundblad L (1978) Does a disturbed insulin release promote hypoglycaemia in alcoholics? Acta Med Scand 204: 57-60

9. Joffe BI, Shires R, Seftel HC, Heding LG (1977) Plasma insulin, C-peptide and glucagon levels in acute phase of ethanol-induced hypoglycaemia. Br Med J II: 678

10. Chalmers RJ, Bennie EH, Johnson RH, Masterton G (1978) Growth hormone, prolactin and corticosteroid responses to insulin hypoglycaemia in alcoholics. Br Med J I: 745-748

11. Wright J (1978) Endocrine effects of alcohol. Clin Endocrinol Metab 7: 351-367

12. Yates FE, Maran JW (1974) Stimulation and inhibition of adrenocorticotropin release. In: Knobil E, Sawyer WH (eds) Handbook of physiology: Endocrinology, vol 4. American Physiological Society, p 367-404

13. Reichlin S (1974) Regulation of somatotrophic hormone secretion. In: Knobil E, Sawyer WH (eds) Handbook of physiology: Endocrinology, vol 4. American Physiological Society, p 404-447

Received: October 6, 1978,

and in revised form: October 4, 1979

Dr. A. Nygren

II Medical Department

Södersjukhuset

S-100 64 Stockholm 38

Sweden 